\title{
Mitä mahdollisuuksia on jalostuksella vaikuttaa maidon koostumukseen ja ravintoarvoon?1)
}

\author{
Kalle Maijala \\ Maatalouden tutkimuskeskus, Kotieläinjalostuslaitos, Tikkurila
}

\section{Possibilities of selective breeding in influencing the composition and nutritive value of milk ${ }^{1)}$}

\author{
Kalle Maijala \\ Agricultural Research Centre, Institute of Animal Breeding, \\ Tikkurila, Finland
}

Abstract. The possibilities of breeding for altering the milk composition were considered on the basis of literature. The following conclusions seemed justifiable:

1) There is variation in the content of most milk constituents. Fat (F) content is about 1.7 times as variable as protein $(\mathrm{P})$ content (Table 1).

2) There are marked differences between breeds. Breeds with high F-content are above average also in the contents of P, SNF and total solids (TS), but their P/F-ratio is low (Table 2).

3) Repeatabilities of contents are reasonably high, $65-70 \%$, so that one year's measurements suffice for evaluating individuals (Table 3).

4) Heritabilities of most contents as well as of P/F-ratio are about $50 \%$ which makes individual selection effective (Table 4).

5) There is an obvious antagonism between milk yield and content of important constituents, both phenotypic and genetic (Table 5).

6) The phenotypic correlations among contents are in most cases positive (Table 6).

7) The genetic correlations among yields as well as among contents are highly positive.

Those between yields and contents are low, and in some cases even negative. A high P/F-ratio is antagonistic to high yields of F or TS (Table 7).

8) Selection based on concentration leads to a decrease in milk yield, and consequently to poor progress in the yield of the particular component. Thus, selection has to be based on yields, and the purpose of the determination of contents is to estimate these yields. The best progress for a yield of a certain component can be obtained by direct selection. Selection for P-yield improves gradually also the P/F-ratio. An almost complete effect can be obtained by selecting only bulls on the basis of Pyields and females on milk yields (Table 8 ).

1) Esitelmä, jonka professori Maijala piti Suomen Maataloustieteellisen Seuran symposiumissa 29. 1. 1974.

1) Lecture given at the symposium of the Scientific Agricultural Society of Finland in Helsinki on January 29, 1974. 
Voin markkinointivaikeudet sekä lisääntynyt tietoisuus maidon valkuaisen ravitsemuksellisesta merkityksestä ovat viimeisten $10-20$ vuoden aikana yhä voimakkaampina nostaneet esiin kysymyksen siitä, olisiko mahdollista tai aiheellista pyrkiä jalostusteitse muuttamaan maidon koostumusta suhteellisesti valkuaisvoittoisemmaksi nykyisestään. Kysymystä on näinä vuosina runsaasti tutkittu eri maissa, erityisesti Yhdysvalloissa. Seuraavan esityksen tarkoituksena on koota tärkeimmät kirjallisuudesta löytyvät tutkimustulokset käytännöllisten johtopäätösten tekemiseksi maidon koostumusta koskevien jalostustavoitteiden ja -menetelmien valintaa varten.

\section{Ainesosien pitoisuuksien vaihtelu}

Tärkeä perusedellytys jalostusvalinnalle on vaihtelun esiintyminen kiinnostuksen kohteina olevissa ominaisuuksissa, minkä vuoksi on laadittu taulukko 1. Siitä nähdään, että tiettyä vaihtelua on kaikissa pitoisuuksissa,

Taulukko 1. Maidon ainesosien pitoisuuksien vaihtelu.

Table 1. Variation in content of milk components.

\begin{tabular}{|c|c|c|c|c|}
\hline $\begin{array}{l}\text { Ominaisuus } \\
\text { Trait }\end{array}$ & $\begin{array}{l}\text { Hajo } \\
\text { Standard } \\
\text { Tutkimusten } \\
\text { luku } \\
\text { No. } \\
\text { of studies }\end{array}$ & $\begin{array}{c}\text { Keskiarvo } \\
\text { Average }\end{array}$ & $\begin{array}{l}\text { Muuntelul } \\
\text { Coefficient of } \\
\text { Tutkimusten } \\
\text { luku } \\
\text { No. } \\
\text { of studies }\end{array}$ & $\begin{array}{l}\text { variation, \% } \\
\text { Keskiarvo } \\
\text { Average }\end{array}$ \\
\hline Rasva $\%(\mathrm{R}-\%)$ Fat $\%(F-\%) \ldots \ldots \ldots$ & 28 & 0.37 & 10 & 7.32 \\
\hline Valkuais \% (V-\%) Protein $\%(P-\%) \ldots$ & 27 & 0.22 & 10 & 5.57 \\
\hline $\begin{array}{c}\text { Rasvaton kuiva-aine } \%(\mathrm{rK}-\%) \\
\text { Solids-not-fat } \%(\text { SNF- } \%)\end{array}$ & 16 & 0.30 & & \\
\hline $\begin{array}{c}\text { Kokonaiskuiva-aine } \%(\mathrm{~K}-\%) \\
\text { Total solids }(T S-\%)\end{array}$ & 11 & 0.60 & & \\
\hline $\begin{aligned} \text { Maitosokeri } \% & (\mathrm{~S}-\%) \\
\text { Lactose } \% & (L-\%)\end{aligned}$ & 6 & 0.18 & & \\
\hline Kaseiini $\%$ Kasein $\%$...................... & 1 & 0.18 & & \\
\hline $\begin{array}{c}\text { Ei-kaseini-valkuais } \% \ldots \ldots \ldots \ldots \ldots \ldots . . . . . . . . . . . . . \\
\text { Non-kasein-protein } \%\end{array}$ & 1 & 0.08 & & \\
\hline $\begin{array}{c}\text { Valkuais/rasva-suhde, } \%(\mathrm{~V} / \mathrm{R}) \\
\text { Protein } / \text { Fat ratio, } \%(P / F)\end{array}$ & 10 & 0.07 & & \\
\hline $\begin{array}{c}\text { Kivennäisaine } \%(\mathrm{~T}-\%) \ldots \ldots \ldots \ldots \ldots \ldots \\
\text { Minerals, } \%(M-\%)\end{array}$ & 1 & 0.05 & & \\
\hline
\end{tabular}

mutta että eri ainesosat ovat țässä suhteessa toisistaan poikkeavia. Rasva-\%:n hajonta on n. 1.7 kertaa niin suuri kuin valkuais- $\%: n$ ja noin 2-kertainen sokeripitoisuuden tai kaseiinipitoisuuden vaihteluun verrattuna. Kivennäispitoisuuden vaihtelu on vain $1 / 7$ rasva- $\%$ :n vaihtelusta. Kaikkein laajinta on vaihtelu kuitenkin kokonaiskuiva-ainepitoisuudessa, jonka vaihtelualueeksi \pm 3 hajonnan perusteella saadaan n. $3.6 \%$-yksikköä, kun vastaava luku 
rasva- $\%$ :lla on 2.2 , rasvattomalla kuiva-aineella 1.8 ja valkuaisella 1.3 . Valkuais/rasva-suhteen vaihtelualueeksi saadaan tällä tavoin 0.42 eli noin $0.60-$ 1.00 silloin, kun keskiarvo on $\mathbf{0 . 8 0}$.

\section{Rotujen väliset erot}

Esimerkkejä rotujen välisestä vaihtelusta maidon koostumuksessa on esitetty taulukossa 2. Sekä U.S.A:n että Ruotsin rotujen keskiarvoista näh-

Taulukko 2. Eri rotujen maidon koostumus

Table 2. Composition of milk of different breeds

\begin{tabular}{|c|c|c|c|c|c|c|c|c|c|c|}
\hline \multirow[b]{2}{*}{$\begin{array}{l}\text { Maa } \\
\text { Country }\end{array}$} & \multirow[b]{2}{*}{$\begin{array}{l}\text { Rotu } \\
\text { Breed }\end{array}$} & \multirow{2}{*}{$\begin{array}{c}\text { Tutkittu- } \\
\text { ja lehmiä } \\
\text { No. of } \\
\text { cows } \\
\text { studied }\end{array}$} & \multirow[b]{2}{*}{$\begin{array}{l}\mathrm{R}-\% \\
F-\%\end{array}$} & \multicolumn{5}{|c|}{$\begin{array}{l}\text { Eri ainesosien pitoisuus, \% } \\
\text { Content of different components }\end{array}$} & \multicolumn{2}{|c|}{$\begin{array}{l}\text { Suhteet } \\
\text { Ratios }\end{array}$} \\
\hline & & & & $\begin{array}{l}\mathrm{V}-\% \\
P-\%\end{array}$ & $\begin{array}{l}\text { rK- } \% \\
\text { SNF-\% }\end{array}$ & $\begin{array}{l}\mathrm{K}-\% \\
\mathrm{TS}-\%\end{array}$ & $\begin{array}{l}\mathrm{S}-\% \\
L-\%\end{array}$ & $\begin{array}{l}\mathrm{T}-\% \\
M-\%\end{array}$ & $\begin{array}{l}\mathrm{V} / \mathrm{R} \\
P / F\end{array}$ & $\begin{array}{l}\mathrm{V} / \mathrm{K} \\
P / T S\end{array}$ \\
\hline U.S.A. & Friisil. Friesian ... & 34000 & 3.65 & 3.13 & 8.50 & 12.16 & 4.82 & 0.69 & 85.0 & 25.8 \\
\hline , & Ayrshire ............. & 6000 & 4.05 & 3.35 & 8.60 & 12.68 & 4.68 & 0.68 & 82.5 & 26.4 \\
\hline , & $\begin{array}{l}\text { Rusk. Sveitsil. ... } \\
\text { Brown Swiss }\end{array}$ & 6000 & 4.16 & 3.53 & 9.00 & 13.20 & 5.04 & 0.73 & 84.8 & 26.7 \\
\hline , & Guernsey ........... & 6300 & 4.87 & 3.61 & 9.06 & 13.97 & 4.88 & 0.74 & 73.8 & 25.9 \\
\hline , & Jersey $\ldots \ldots \ldots \ldots \ldots$ & 4700 & 5.22 & 3.81 & 9.34 & 14.58 & 4.89 & 0.71 & 73.3 & 26.3 \\
\hline Ruotsi & Friisil. Friesian... & 600 & 4.00 & 3.27 & & 12.66 & & & 81.8 & 25.8 \\
\hline Sweden & $\begin{array}{l}\text { Punakirjava ........ } \\
\text { Red \& White }\end{array}$ & 1362 & 4.17 & 3.31 & & 13.02 & & & 79.4 & 25.4 \\
\hline , & Nupokarja Polled & 147 & 4.41 & 3.53 & & 13.61 & & & 80.0 & 25.9 \\
\hline , & Jersey ............... & 82 & 5.71 & 3.93 & & 14.78 & & & 68.8 & 26.6 \\
\hline $\begin{array}{l}\text { Saksa } \\
\text { Germany }\end{array}$ & Friisil. Friesian... & 3300 & & 3.37 & 9.02 & & 4.80 & & & \\
\hline Suomi & Ayrshire $-73 \ldots$ & 5300 & 4.49 & 3.51 & & & & & 79.0 & \\
\hline Finland & $-72 \ldots$ & 1500 & 4.45 & 3.59 & & & & & 82.0 & \\
\hline
\end{tabular}

dään, että valkuais- $\%$, rasvaton kuiva-aine- $\%$ ja kokonaiskuiva-aine- $\%$ nousevat rasva- $\%$ :n mukana. Valkuais- $\%$ :ssa on kuitenkin esim. amerikkalaisen friisiläisen ja jerseyn välillä eroa vain $0.68 \%$-yksikköä, kun ero rasva- $\%$ :ssa on $1.57 \%$-yksikköä. Rasvattomassa kuiva-aineessa on eroa $0.84 \%$ ja kokonaiskuiva-aineessa $2.42 \%$. Koska valkuais- $\%$ ei laske yhtä nopeasti kuin rasva- $\%$, on valkuais/rasva-suhde yleensä suurin laihamaitoisilla roduilla. Valkuaisen osuus kokonaiskuiva-aineesta ei kuitenkaan nouse rasva-\%:n laskiessa.

Amerikkalaisen, ruotsalaisen ja saksalaisen friisiläisen keskinäinen vertailu osoittaa samankin rodun olevan eri maissa vähän eri tasolla. Samaa voidaan nähdä amerikkalaisen ja suomalaisen ayrshiren välisestä vertailusta.

Rotujen välisillä eroilla on nykyisin entistä suurempi merkitys, kun hyvät liikenneyhteydet sekä keinosiemennys- ja pakastetekniikka tekevät mahdolliseksi verraten nopean rodunvaihdon, jos se katsotaan aiheelliseksi. Aiheellisuutta arvioitaessa on kuitenkin otettava huomioon paljon muitakin näkökohtia kuin maidon koostumus. 


\section{Toistuvuus}

Ominaisuuden toistuvuus samalla eläimellä lypsykaudesta tai vuodesta toiseen on hyvä tuntea sen vuoksi, että se antaa ylärajan periytymisasteen arvioille sekä osoittaa, onko tarpeen mitata ko. ominaisuutta vuodesta toiseen. Taulukossa 3 esitetyistä useitten tutkimusten keskiarvoista nähdään,

Taulukko 3. Maidon ainesosien pitoisuuksien toistuvuus.

Table 3. Repeatability of the contents of milk components.

\begin{tabular}{lccc}
\hline Ominaisuus & Tutkimusten luku & Lypsykausien luku & Keskim. toistuvuus \% \\
Trait & No. of studies & No. of lactations & Average repeatability \% \\
\hline
\end{tabular}

\begin{tabular}{lrrr} 
R- $\%-F-\% \ldots \ldots \ldots$. & 11 & 12900 & 72 \\
V- $\%-P-\% \ldots \ldots \ldots .$. & 10 & 12400 & 65 \\
rK- $\%-S N F-\% \ldots \ldots$. & 10 & 12400 & 65 \\
K- $\%-T S-\% \ldots \ldots \ldots$. & 8 & 10800 & 73 \\
\hline
\end{tabular}

että maidon väkevyys on varsin voimakkaasti yksilöllinen ominaisuus, jonka arvioimiseen ei välttämättä tarvita sen jatkuvaa mittaamista. Tärkeintä on mitata sitä ensikkolypsykauden aikana.

\section{Periytymisasteet}

Jalostusmahdollisuuksien kannalta keskeisen tärkeät periytymisasteet on esitetty taulukossa 4. Voidaan todeta, että noin puolet useimpien pitoisuuk-

Taulukko 4. Maidon ainesosien pitoisuuksien periytymisasteet.

Table 4. Heritability of the contents of milk components.

\begin{tabular}{lrrr}
\hline $\begin{array}{l}\text { Ominaisuus } \\
\text { Trait }\end{array}$ & $\begin{array}{c}\text { Tutkimusten luku } \\
\text { No. of studies }\end{array}$ & $\begin{array}{c}\text { Lehmien luku } \\
\text { No. of cows }\end{array}$ & $\begin{array}{c}\text { Periytymisaste } \\
\text { Heritability }\end{array}$ \\
\hline
\end{tabular}

1) Punnitsemattomia keskiarvoja (punnitut keskiarvot suluissa)

1) Unweighted averages (weighted averages in brackets)

sien muuntelusta on perinnöllistä. Alhaisin arvio on saatu maitosokerin pitoisuudelle ja sekin on $41 \%$, mikä tekee mahdolliseksi yksilövalinnan. Esitetynkaltaisten periytymisasteiden saaminen edellyttää kuitenkin, että mittaukset on tehty luotettavasti ja että tärkeimmät virhelähteet on eliminoitu. 
Maidon koostumuksen muuttamiseen tähțävien jalostustoimien aiheellisuus riippuu suuresti niiden seurausilmiöistä, erityisesti vaikutuksesta maidon ja sen ainesosien tuotoksiin. Taulukosta 5 käy ilmi, että maidon väke-

Taulukko 5. Maitotuotoksen ja ainesosien pitoisuuksien välisiä vuorosuhteita.

Table 5. Correlations between milk yield and contents of milk components.

\begin{tabular}{|c|c|c|c|c|c|c|}
\hline \multirow[b]{2}{*}{$\begin{array}{l}\text { Ominaisuus } \\
\text { Trait }\end{array}$} & \multicolumn{3}{|c|}{$\begin{array}{l}\text { Ilmiasuisia vuorosuhteita } \\
\text { Phenotypic correlations }\end{array}$} & \multicolumn{3}{|c|}{$\begin{array}{c}\text { Perinnöllisiä vuorosuhteita } \\
\text { Genetic correlations }\end{array}$} \\
\hline & $\begin{array}{c}\text { Tutki- } \\
\text { musten } \\
\text { luku } \\
\text { No. of } \\
\text { studies }\end{array}$ & $\begin{array}{l}\text { Lehmien } \\
\text { luku } \\
\text { No. of } \\
\text { cows }\end{array}$ & $r_{P}$ & $\begin{array}{c}\text { Tutki- } \\
\text { musten } \\
\text { luku } \\
\text { No. of } \\
\text { studies }\end{array}$ & $\begin{array}{l}\text { Lehmien } \\
\text { luku } \\
\text { No. of } \\
\text { cows }\end{array}$ & $\mathrm{r}_{\mathrm{G}}$ \\
\hline 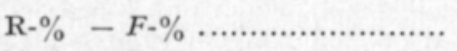 & 10 & 65000 & -0.22 & 10 & 86000 & -0.35 \\
\hline 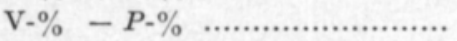 & 3 & 3800 & -0.30 & 3 & 25000 & -0.31 \\
\hline rK- $\%-S N F-\%$ & 5 & 26000 & -0.15 & 5 & 47000 & -0.21 \\
\hline 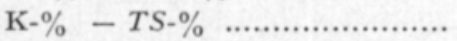 & 2 & 20300 & -0.23 & 4 & 43000 & -0.34 \\
\hline 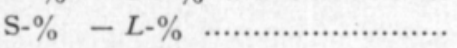 & 1 & 814 & 0.08 & & & \\
\hline $\mathrm{T}-\% \quad-M-\%$ & 1 & 814 & -0.05 & & & \\
\hline 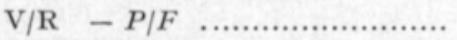 & & & & 2 & 24600 & 0.06 \\
\hline
\end{tabular}

vyyden ja määrän välillä yleensä vallitsee selvä antagonismi sekä ilmiasui sesti että perinnöllisesti. Perinnöllinen vieronta on suunnilleen yhtä voima kasta sekä rasva-\%:iin, valkuais-\%:iin että kokonaiskuiva-aine-\%:iin nähden. Rasvattoman kuiva-aineen osalta yhteys näyttää olevan hieman löyhempi, johtuen ilmeisesti sokeri- ja kivennäispitoisuuksien varsin löyhästä yhteydestä maitomäärään. Valkuais/rasva-suhteen osalta ei antagonismia näytä olevan.

Pitoisuuksien keskinäiset ilmiasuiset riippuvuudet on esitetty taulukossa 6 . Vuorosuhteet ovat pääasiassa positiivisia; huomattavin poikkeus on so-

Taulukko 6. Ilmiasuisia vuorosuhteita maidon ainesosien pitoisuuksien kesken

(RoBERTSON ym. 1956). 465 skotlantilaista ay-lehmää.

Table 6. Phenotypic correlations among contents of milk components

(Robertson et. al. 1956). 465 Scottish Ayrshires.

\begin{tabular}{|c|c|c|c|c|c|}
\hline $\begin{array}{l}\text { Ominaisuus } \\
\text { Trait }\end{array}$ & $\begin{array}{l}\text { rK- \% } \\
S N F-\%\end{array}$ & $\begin{array}{l}\text { V- } \% \\
P-\%\end{array}$ & $\begin{array}{c}\text { Kaseini- } \% \\
\text { Kasein-\% }\end{array}$ & $\begin{array}{l}\mathrm{S}-\% \\
L-\%\end{array}$ & $\begin{array}{l}\text { T- } \% \\
M-\%\end{array}$ \\
\hline $\mathrm{R}-\% \quad-F-\% \quad \ldots \ldots \ldots \ldots$ & 0.40 & 0.42 & 0.43 & 0.11 & -0.03 \\
\hline rK- $\%-S N F-\%$ & & 0.81 & 0.87 & 0.50 & 0.12 \\
\hline $\mathrm{V}-\% \quad-P-\% \ldots \ldots \ldots \ldots$ & & & 0.93 & -0.01 & 0.10 \\
\hline Kaseiini- $\%$ - Kasein- $\%$ & & & & 0.17 & 0.00 \\
\hline $\mathrm{S}-\%-L-\% \quad \ldots \ldots \ldots \ldots \ldots$ & & & & & -0.28 \\
\hline
\end{tabular}


keri- ja kivennäispitoisuuksien välinen vieronta. Rasvattoman kuiva-aineen ja valkuaisen pitoisuuksien vaihtelu näyttää määräytyvän suuresti kaseiini$\%:$ n vaihtelusta.

Perinnölliset yhteydet nähdään taulukosta 7 , joka perustuu viiteen ame-

Taulukko 7. Perinnöllisiä vuorosuhteita maidon ainesosien tuotosmäärien ja pitoisuuksien kesken. (Lävistäjän alapuolella lehmien luvut tuhansina sekä tutkimusten lukumäärät).

Table 7. Genetic correlations among yield and contents of milk components (below the diagonal the number of cows in thousands and the number of studies).

\begin{tabular}{|c|c|c|c|c|c|c|c|c|c|c|c|}
\hline $\begin{array}{l}\text { Ominaisuus } \\
\text { Trait }\end{array}$ & $\begin{array}{l}\text { M } \\
M\end{array}$ & $\begin{array}{l}\mathrm{R} \\
F\end{array}$ & $\begin{array}{l}\mathrm{rK} \\
S N F\end{array}$ & $\begin{array}{l}\mathrm{K} \\
T S\end{array}$ & $\begin{array}{l}\mathrm{V} \\
P\end{array}$ & $\begin{array}{l}\text { ST } \\
L M\end{array}$ & $\begin{array}{l}\mathrm{R}-\% \\
F-\%\end{array}$ & $\begin{array}{l}\text { rK- } \% \\
\text { SNF- } \%\end{array}$ & $\begin{array}{l}\mathrm{K}-\% \\
\mathrm{TS}-\%\end{array}$ & $\begin{array}{l}\mathrm{V}-\% \\
P-\%\end{array}$ & $\begin{array}{l}\mathrm{V} / \mathrm{R} \\
P / F\end{array}$ \\
\hline$\left\{\begin{array}{l}\text { Maitotuotos (M) } \\
\text { Milk yield }(M)\end{array}\right.$ & & .73 & .95 & .92 & .79 & .99 & -.37 & -.16 & -.34 & -.28 & 0.5 \\
\hline $\begin{array}{l}\text { Rasvatuotos }(\mathrm{R}) \\
\text { Fat yield }(F)\end{array}$ & $22 / 5$ & & .80 & .90 & .82 & .74 & .33 & .22 & .33 & .23 & -.50 \\
\hline $\begin{array}{l}\text { Rasvt. k.-a. tuotos (rK) } \\
\text { SNF-yield }(S N F)\end{array}$ & $22 / 5$ & $22 / 5$ & & .98 & .89 & 1.00 & -.24 & .08 & -.09 & -.06 & .06 \\
\hline $\begin{array}{l}\text { Kuiva-ainetuotos (K) ... } \\
\text { TS-yield (TS) }\end{array}$ & $18 / 4$ & $18 / 4$ & $18 / 4$ & & .93 & .97 & -.03 & .11 & .04 & .04 & -.15 \\
\hline $\begin{array}{l}\text { Valkuaistuotots }(\mathrm{V}) \\
\text { Protein yield }(P)\end{array}$ & $10 / 3$ & $10 / 3$ & $10 / 3$ & $10 / 3$ & & .73 & .13 & .33 & .24 & .31 & .08 \\
\hline $\begin{array}{l}\text { Sokeri + kivennäis- } \\
\text { tuotos (ST) .............. } \\
\text { Lactose + Mineral } \\
\text { yield }(L M)\end{array}$ & $5 / 1$ & $5 / 1$ & $5 / 1$ & $5 / 1$ & $5 / 1$ & & -.23 & -.03 & -.18 & -.18 & .09 \\
\hline $\mathrm{R}-\%-F-\%$ & $23 / 6$ & $22 / 5$ & $22 / 5$ & $18 / 4$ & $10 / 3$ & $5 / 1$ & & .54 & .89 & .61 & -.77 \\
\hline rK- $\%-S N F-\% \ldots \ldots \ldots$. & $23 / 6$ & $22 / 5$ & $22 / 5$ & $18 / 4$ & $10 / 3$ & $5 / 1$ & $23 / 6$ & & .86 & .81 & .02 \\
\hline $\mathrm{K}-\%-T S-\% \quad \ldots \ldots \ldots . .$. & $18 / 4$ & $18 / 4$ & $18 / 4$ & $14 / 4$ & $10 / 3$ & $5 / 1$ & $18 / 4$ & $18 / 4$ & & .81 & -.49 \\
\hline $\mathrm{V}-\%-P-\% \quad \ldots \ldots \ldots . .$. & $10 / 4$ & $10 / 3$ & $10 / 3$ & $10 / 3$ & $10 / 3$ & $5 / 1$ & $10 / 4$ & $10 / 4$ & $10 / 3$ & & .09 \\
\hline $\mathrm{V} / \mathrm{R}-P / F \ldots \ldots \ldots \ldots \ldots$ & $5 / 1$ & $5 / 1$ & $5 / 1$ & $5 / 1$ & $5 / 1$ & $5 / 1$ & $5 / 1$ & $5 / 1$ & $5 / 1$ & & \\
\hline
\end{tabular}

rikkalaiseen ja yhteen englantilaiseen tutkimukseen. Tuotosmäärien keskinäiset perinnölliset vuorosuhteet ovat kaikki yli 0.70 ja eräät niistä ovat lähellä täydellistä, kuten esim. sokeri + kivennäismäärän riippuvuus maițotuotoksesta tai rasvattoman kuiva-aineen tuotoksesta. Valkuaistuotoksen ja kuiva-ainetuotoksen muuntelut riippuvat taulukon mukaan 93-prosenttisesti samoista perintötekijöistä. Maitotuotoksen merkitys ainesosien tuotoksille on kauttaaltaan paljon suurempi kuin väkevyyksien merkitys. Valkuaistuotosten vuorosuhteet kaikkiin väkevyyksiin ja myös valkuais/rasva-suhteeseen ovat myönteiset, joten valkuaismääriin perustuvan valinnan ei pitäisi johtaa väkevyyden alenemiseen. Samaa voidaan sanoa rasvatuotoksiin perustuvasta valinnasta, paitsi että se heikentää valkuais/rasva-suhdetta.

Pitoisuuksien keskinäiset perinnölliset vuorosuhteet ovat samansuuntaisia, mutta yleensä kiinteämpiä kuin vastaavat ilmiasuiset vuorosuhteet taulukossa 6. Rasva-\%:n ja valkuais- \%:n perintötekijöistä olisi taulukon mukaan yhteisiä n. $60 \%$; yhteys on siis varsin selvä, mutta ei kuitenkaan täydelli- 
nen. Sekä rasvan että kokonaiskuiva-aineen pitoisuudet ovat vierovia valkuais/rasva-suhteeseen nähden. Kuvioista 1 ja 2 voidaan nähdä, että eri rotujen valkuais- $\%$ :t sekä valkuais/rasva-suhteet riippuvat ratkaisevasti niiden rasva-\%:sta: sen ollessa sama ovat rotujen väliset erot pieniä.

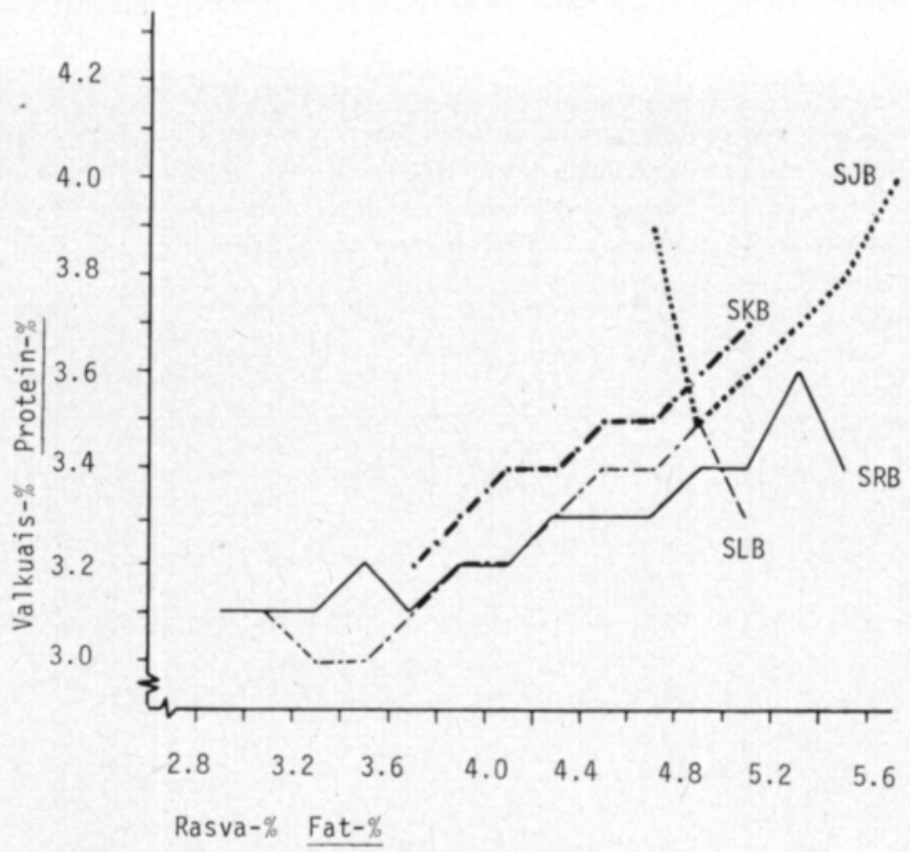

Kuvio 1. Ruotsin karjarotujen valkuaispitoisuudet eri rasvapitoisuuksilla (Roos, 1971). SJB $=$ Jersey, $\mathrm{SKB}=$ nupokarja, $\mathrm{SLB}=$ friisiläiskarja, SRB - punakirjava karja.

Figure 1. Protein content of Swedish cattle breeds at different fat content levels (Roos, 1971). $S J B=$ Jersey, $S K B=$ Polled, $S L B=$ Friesian, $S R B=$ Red and White.

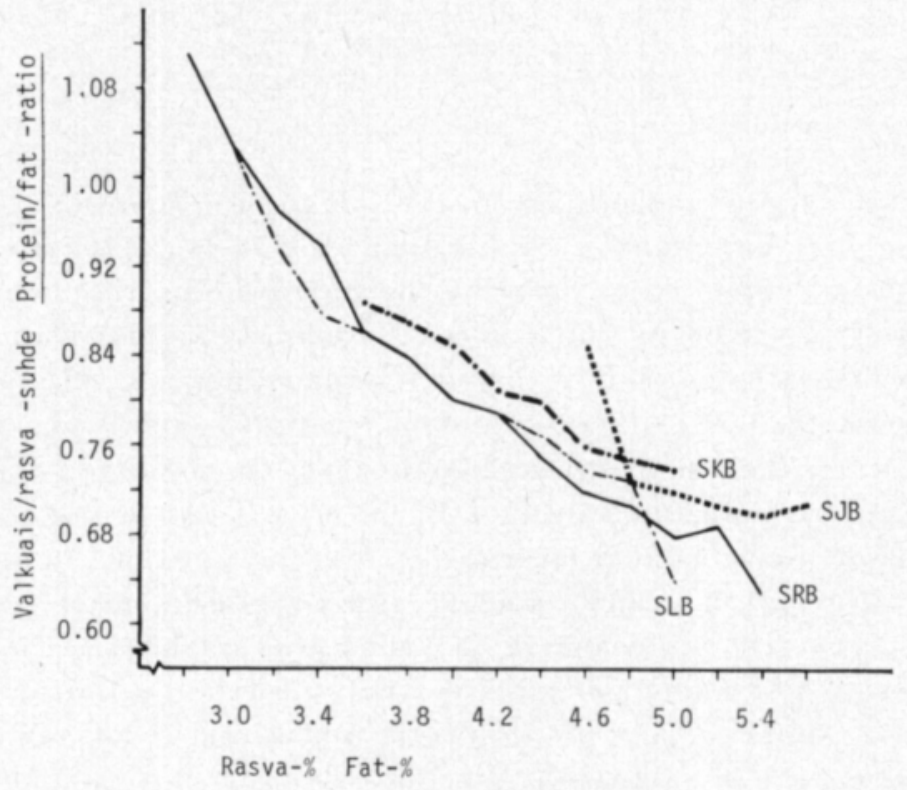

Kuvio 2. Ruotsin karjarotujen valkuais/rasva-suhteet eri rasvapitoisuuksilla (Roos, 1971). Rotuselitykset kuten kuviossa 1.

Figure 2. Protein/fat-ratios of Swedish breeds at different levels of fat content (Roos, 1971). Breeds as in Fig. 1. 
Useat tutkijat ovat saamiensa tai kirjallisuudesta löytämiensä periytymisasteiden, hajonnan ja vuorosuhteiden arvioiden nojalla laskeneet eri valintaperusteita käyttäen odotettavissa olevat perinnölliset edistymisnopeudet sukupolvea kohti sekä itse valitussa ominaisuudessa että muissa ominaisuuksissa. Taulukkoa 8 varten kerättiin tulokset 11 tutkimuksesta, mutta ne oli keskiarvojen laskua varten muunnettava suhteellisiksi luvuiksi, koska mm. hajonnat olivat eri tutkimuksissa olleet erilaisia.

Taulukon lukuja voidaan verrata lähinnä vain sarakkeiden sisällä, mutta jotakin voidaan päätellä myös rivien sisäisistä vertailuista. Taulukosta tehtävät tärkeimmät johtopäätökset ovat seuraavat:

1) Tuotosmääriin perustuva valinta johtaa kohtalaiseen edistymiseen myös muiden tuotosten jalostuksessa.

2) Kunkin tuotoksen jalostuksessa päästään parhaiten eteenpäin siihen itseensä kohdistuvalla valinnalla. Esimerkkinä poikkeuksista voidaan mainita maitotuotoksiin perustuvan valinnan vaikutukset kokonaiskuiva-aineen ja rasvattoman kuiva-aineen tuotoksiin sekä rasvattoman kuiva-aineen tuotoksiin perustuvan valinnan vaikutus valkuaistuotoksiin. Nämä poikkeukset perustuvat kuitenkin harvoihin tutkimuksiin.

3) Tuotosmääriin perustuva valinta pyrkii useissa tapauksissa alentamaan maidon väkevyyttä. Kuitenkin rasva- tai valkuaistuotoksiin perustuva valinta johtaa hienoiseen pitoisuuksienkin paranemiseen. Eroa näillä on lähinnä siinä, että rasvatuotosvalinta heikentää, valkuais-/rasvasuhdetta, kun taas valkuaistuotosvalinta parantaa sitä jonkin verran.

4) Erään tutkimuksen mukaan (SYRSTAD, 1971) järjestelmä, jossa lehmät valitaan maitomäärien perusteella ja sonnit valkuaistuotosten perusteella, johtaa valkuaistuotosten jalostuksessa $97 \%$ :n tehoon suoraan valintaan verrattuna. Maitotuotosvalinta antaa $91 \%$ ja rasvatuotosvalinta $88 \%$ tehon. Täten tähänastisen jalostustyön voidaan päätellä palvelleen paljolti myös valkuaistuotosten kehittämistä. Kääntäen on pääteltävissä, ettei valkuaistuotosjalostukseen siirtyminen merkitse oleellista muutosta jalostustyössä.

5) Pitoisuuksiin perustuva valinta vaikuttaa heikentävästi useimpiin tuotoksiin, lukuunottamatta rasva- ja valkuaistuotoksia.

6) Pitoisuuksiin perustuvat valintajärjestelmät edistävät huomattavasti myös muiden ainesosien pitoisuuksien kehittämistä, mutta rasva-\%:iin tai kuiva-aine-\%:iin perustuvat valinnat heikentävät valkuais/rasvasuhdetta.

7) Valkuais/rasva-suhteeseen perustuva valinta heikentää maidon, rasvan ja energian tuotoksia, mutta edistää jonkin verran valkuaisen ja rasvattoman kuiva-aineen tuotoksia. Samoin se edistää valkuais-\%:ia, mutta alentaa rasva- $\%:$ ia ja kuiva-aine- $\%$ :ia. 


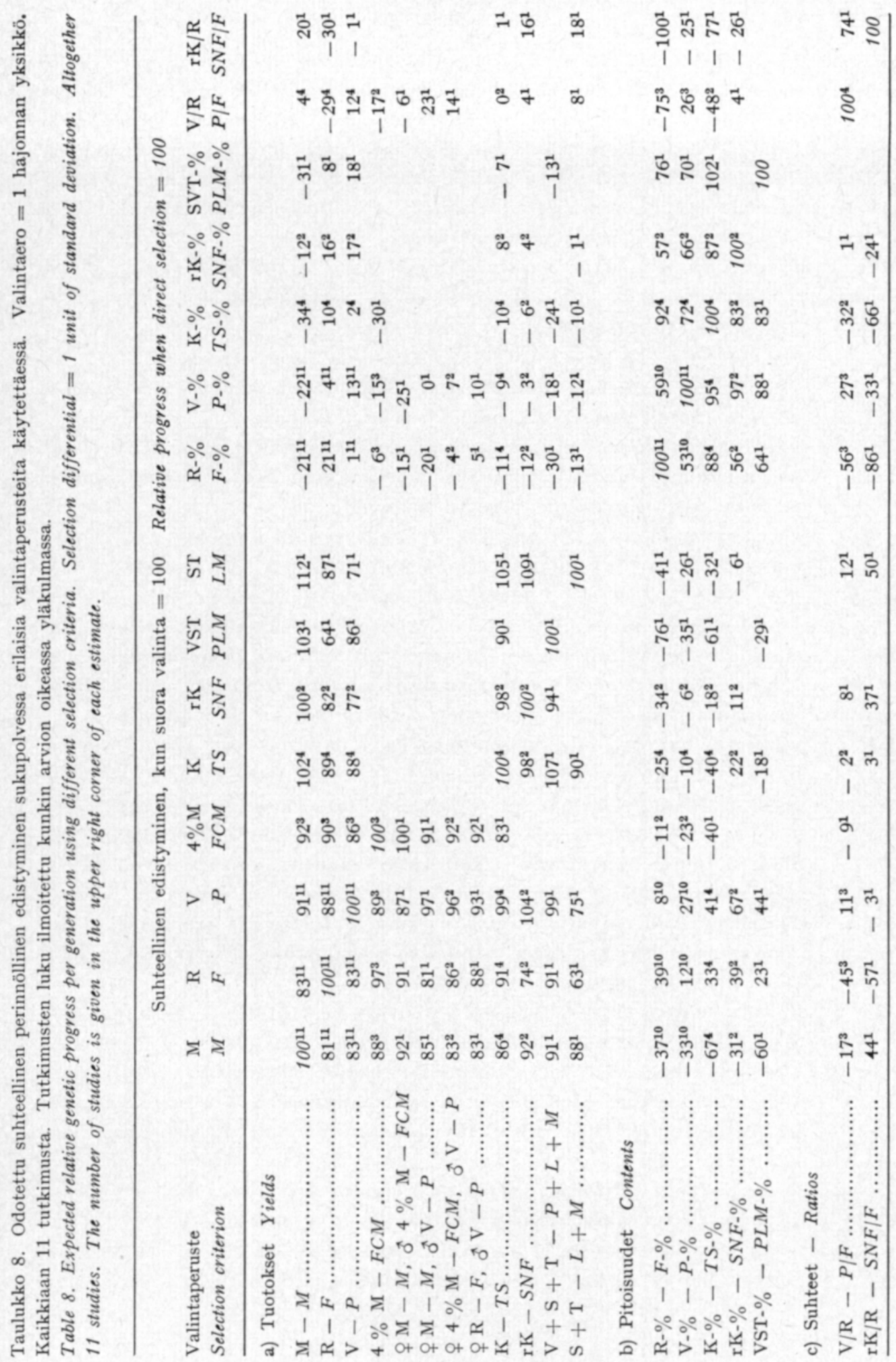


Joissakin tutkimuksissa on pyritty myös selvittämään sonnien jälkeläisarvostelun mahdollisuuksia ja merkitystä tyttärien maidon valkuaispitoisuuden suhteen. BERGManN (1969) arvosteli 29 sonnia vähintään 15 tyttären perusteella sekä Roos (1971) 56 sonnia ensikkotyttärien perusteella ja 41 sonnia 3. lypsykauden tyttärien perusteella. Tytärryhmien samanaikaiset hajonnat rasva- $\%$ :n ja valkuais- $\%: n$ mukaan on esitetty kuviossa 3 . Siițä nähdään,
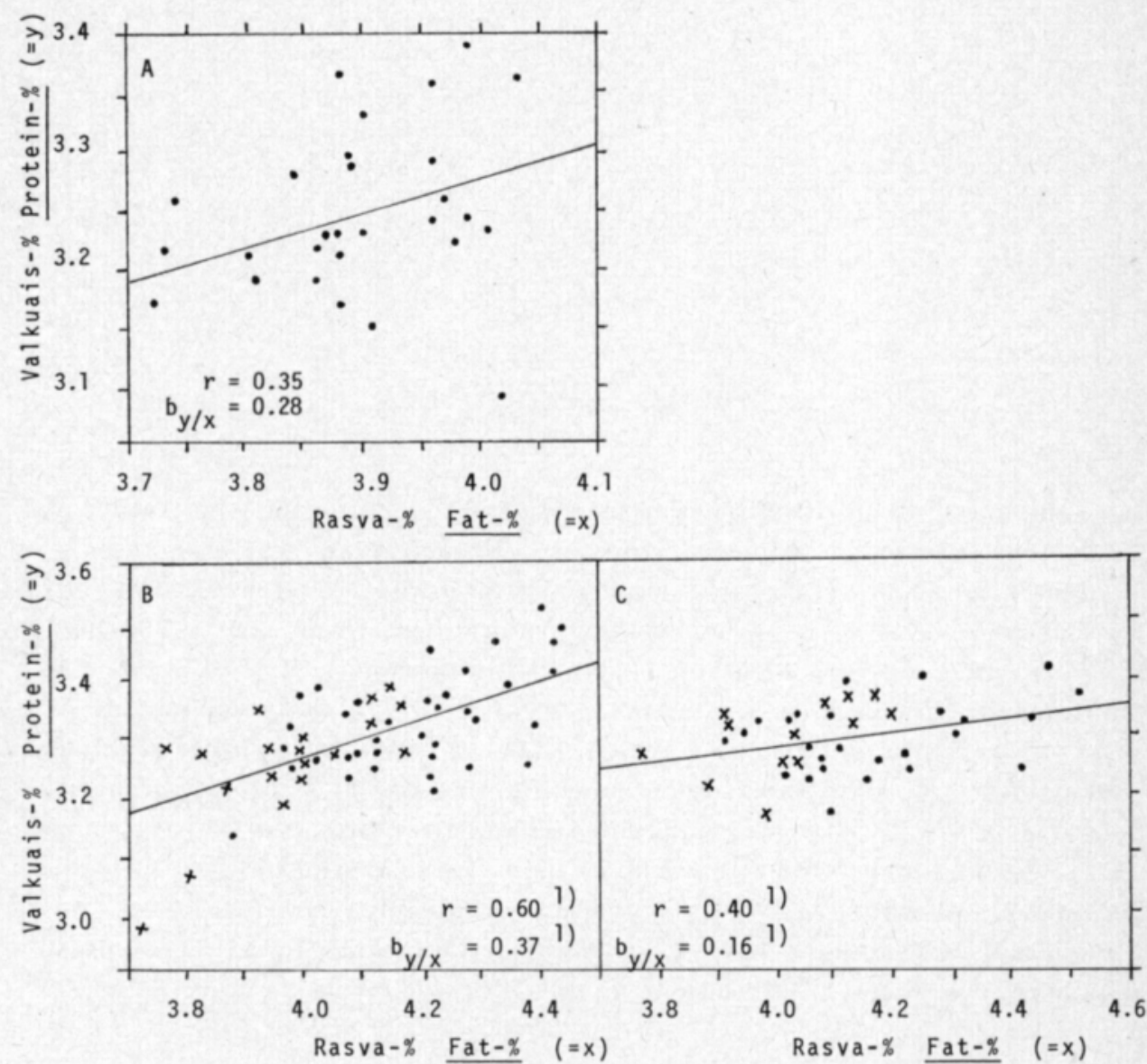

Kuvio 3. Sonnien jälkeläisryhmien rasva- $\%: n$ ja valkuais- $\%: n$ välinen riippuvuus. A. Ruskea sveitsiläinen (Bergmann. 1969), B ja C. Ruotsalaiset SRB (.) ja SLB (x) (Roos, 1971). $\mathrm{B}=$ ensikot, $\mathrm{C}=$ III lypsykausi, 1 ) = rotujen sisäisesti

Figure 3. Interdependence between protein and fat contents of progeny groups of bulls. A. Brown Swiss (Bergmann, 1969), B and C. Swedish Red \& White (.) and Friesian (x) (Roos, 1971). $B=1$ st lactation, $C=3$ rd lactation, 1$)=$ within breeds.

että valkuais-\% nousee rasva- \%:n mukana myös sonnien jälkeläisarvostelutuloksissa, mutta että samallakin rasvapitoisuustasolla on sonnien kesken ilmeistä vaihtelua valkuaispitoisuudessa. Nykyisin, kun sonnilta voi olla 
tallessa $20-30$ tuhatta pakastesiemenannosta, voidaan äärimmäisiä tapauksia esim. V/R-suhteessa käyttää tehokkaasti hyväksi jalostuksessa, mikäli se katsotaan aiheelliseksi.

Taulukko 9. Tyttärien valkuaispitoisuuden mukaan kolmeen ryhmään jaettujen ruskeiden sveitsiläissonnien tyttärien ominaisuuksia (29 sonnia BERGMAN Nin tutkimuksesta 1969).

Table 9. Characteristics of progeny groups of Brown Swiss bulls grouped according to daughters' protein content (29 bulls from the study by BERGMANN, 1969).

Eri ominaisuuksien keskiarvot

Average performance in different traits

I

II

III

\begin{tabular}{|c|c|c|c|}
\hline Sonnien luku - No. of bulls .............. & 10 & 10 & 9 \\
\hline Valkuais- $\%$ - Protein- $\%$................... & 3.322 & 3.232 & 3.166 \\
\hline Rasva-\% - Fat-\% ......................... & 3.931 & 3.892 & 3.842 \\
\hline 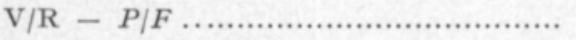 & 84.53 & 83.09 & 82.44 \\
\hline Maitoa kg - Milk kg ....................... & 3838 & 3782 & 3824 \\
\hline Valkuaista kg - Protein $\mathrm{kg}$................ & 127.5 & 122.2 & 121.1 \\
\hline 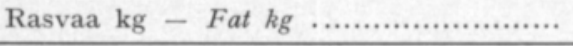 & 150.9 & 147.2 & 146.9 \\
\hline
\end{tabular}

Taulukossa 9 on Bergmannin arvostelemat sonnit jaettu tyttärien valkuais- $\%$ :n perusteella kolmeen ryhmään. Jos verrataan parhaimman ja heikoimman ryhmän keskiarvoja nähdään, että $0.156 \%$ :n eroa valkuais- $\%$ :ssa on seurannut $0.089 \%$ :n suuruinen samansuuntainen ero rasva- $\%:$ :ssa, $2.09 \%$ :n ero V/R-suhteessa, $6.4 \mathrm{~kg}: \mathrm{n}$ ero valkuaistuotoksessa ja $4.0 \mathrm{~kg}: \mathrm{n}$ ero rasvatuotoksessa. Rasvatuotoksen mukaan ryhmiteltäessä oli eroa rasvatuotoksessa $17.26 \mathrm{~kg}$ ja valkuaistuotoksessa $12.06 \mathrm{~kg}$, kun taas valkuaistuotoksen mukainen ryhmittely antoi eroksi rasvatuotoksessa $14.7 \mathrm{~kg}$ ja valkuaistuotoksessa $14.5 \mathrm{~kg}$. Tuotosten mukainen ryhmittely antoi siis tässäkin monta kertaa suuremman eron tuotoksissa kuin valkuaispitoisuuksien mukainen ryhmittely. Valkuaistuotosten mukaisen ryhmittelyn aiheuttamassa erossa oli valkuais/rasva-suhde $14.5 / 14.7=98.6 \%$, kun tämä luku rasvatuotosten mukaisen ryhmittelyn jälkeen oli $12.06 / 17.26=69.9 \%$.

\section{Tiivistelmä}

Jalostuksellisia mahdollisuuksia maidon koostumuksen muuttamiseen tarkasteltiin kirjallisuustietojen perusteella. Mm. seuraavat johtopäätökset näyttivät oikeutetuilta:

1) Useimpien maidon ainesosien pitoisuuksissa esiintyy selvää vaihtelua. Rasva-\%:n muuntelu on noin 1.7 kertaa laajempaa kuin valkuais- $\%$ :n (Taul. 1.).

2) Rotujen välillä on huomattavia eroja. Roduilla, joilla on korkea rasva- $\%$, on myös keskimääräistä korkeampi valkuais- $\%$, rasvattoman 
kuiva-aineen $\%$ ja kokonaiskuiva-aine- $\%$, mutta niiden valkuais/rasvasuhde on alhainen (Taul. 2.).

3) Pitoisuuksien toistuvuudet ovat suhteellisen suuria, $60-70 \%$, niin että yhden vuoden määritykset riittävät yksilöiden arvosteluun (Taul. 3.).

4) Useimpien pitoisuuksien samoin kuin valkuais/rasva-suhteenkin periytymisasteet ovat noin $50 \%$, mikä tekee yksilövalinnan mahdolliseksi (Taul. 4.).

5) Maitotuotoksen ja tärkeitten ainesosien pitoisuuksien välillä on sekä ilmiasuisesti että perinnöllisesti ilmeinen antagonismi (Taul. 5.).

6) Pitoisuuksien keskinäiset ilmiasuiset vuorosuhteet ovat useimmissa tapauksissa myönteisiä (Taul. 6.).

7) Tuotosten kuten myös pitoisuuksien keskinäiset perinnölliset vuorosuhteet ovat hyvin kiinteitä ja myönteisiä. Tuotosten ja pitoisuuksien väliset perinnölliset vuorosuhteet ovat löyhiä ja eräissä tapauksissa jopa kielteisiä. Korkea valkuais/rasva-suhde on antagonistinen suurille rasvan tai kokonaiskuiva-aineen tuotoksille (Taul. 7.).

8) Väkevyyteen perustuva valinta johtaa maitotuotosten alenemiseen ja sen seurauksena heikkoon edistymiseen ko. ainesosan tuotoksessa. Valinta on siten perustettava tuotoksiin, ja pitoisuuksien määrittämisen tarkoituksena on voida arvioida nämä tuotokset. Paras edistyminen tietyn ainesosan tuotoksen suhteen voidaan saavuttaa sen suoralla valinnalla. Valkuaistuotosvalinta parantaa vähitellen myös valkuais/ rasva-suhdetta. Lähes täydellinen teho voidaan saavuttaa valitsemalla vain sonnit valkuaistuotosten perusteella ja lehmät vain maitotuotosten perusteella (Taul. 8.).

\section{KIRJALLISUUSLUETTELO - REFERENCES}

Bergmann, J. 1969. Der Eiweissgehalt in der Milch des schweizerischen Braunviehs. Züchterische Grundlagen für die Einbeziehung des Eiweissgehaltes in die Selektion. Diss. Göttingen, 133 p.

Roos, A. 1969. Mjölkens sammansättning ur avelssynpunkt. (= Composition of milk from a breeding point of view). Swedish with an English summary. SHS Meddelande 41. 41. $110 \mathrm{p}$.

SYrstad, O. 1971. Seleksjon for proteininnhald i mjølk. Summary: Selection for protein content in milk. Meld. fra Norges landb. høgsk. 50 (27): 11 p.

Luettelo taulukoissa käytetystä kirjallisuudesta saatavissa kirjoittajalta.

List of references cited in the Tables is obtainable from the author. 